\title{
A perfect symbiosis: Curaçao, the Netherlands and financial offshore services, I95I-20I3
}

\author{
TIJN VAN BEURDEN and JOOST JONKER * \\ *University of Amsterdam
}

\begin{abstract}
Analysing Curaçao as an offshore financial centre from its inception to its gradual decline, we find that it originated and evolved in close concert with the demand for such services from Western countries. Dutch banks and multinationals spearheaded the creation of institutions on the island facilitating tax avoidance. In this they were aided and abetted by their government, which firmly supported the Antilles in getting access to bilateral tax treaties, notably the one with the United States. Until the mid I980s Curaçao flourished, but then found it increasingly difficult to keep a competitive advantage over other offshore centres. Meanwhile the Curaçao connection had enabled the Netherlands to turn itself into a hub for international revenue flows that today still feed both Dutch tax income and specialised financial, legal and accounting services.
\end{abstract}

Keywords: Curaçao, The Netherlands, offshore financial centres, tax avoidance

JEL classification: $\mathrm{N}_{24}, \mathrm{~N}_{2} 6, \mathrm{~N}_{44}, \mathrm{~N}_{4} 6$

Offshore financial centres (OFCs) tend to have a bad press. They are pilloried for providing legal and financial facilities helping countries, corporations and High Net Worth Individuals (HNWIs) to escape economic sanctions, taxes and anti-money-laundering regulation. As a rule the journalists and members of parliament castigating OFCs focus on the supply side of these services, conveniently overlooking the fact that they flourish largely by virtue of the demand for them from their own, Western countries.

By contrast, the academic literature on OFCs does discuss push-and-pull factors in their evolution and services (Johns I983, p. I86; Roberts I996, pp. I I, I2; Palan 2002, p. I 52; Boise and Morriss 2009, p. 408; Vlcek 2012, p. I 57; Van Koningsveld 201 5 , pp. I29-3 I). In this article we add to that literature by demonstrating that the Curaçao

Dr M. J. C. van Beurden is a private scholar, email: mvbeur@live.nl. J. Jonker is NEHA Professor of Business History, University of Amsterdam, and Senior Research Fellow at the International Institute of Social History, Amsterdam. Corresponding author: J. Jonker, Kloveniersburgwal 48, IOI2 CX Amsterdam, email: j.jonker@uva.nl. This article draws on research presented in extended form in M. J. C. van Beurden, 'De Curaçaose offshore: Ontstaan, groei en neergang van een belastingparadijs, I95I-20I3', PhD dissertation, University of Amsterdam, 20I8. We are grateful to two anonymous referees for their helpful comments. 
OFC evolved in close symbiosis with the Netherlands. Curaçao became a successful OFC largely because Dutch corporations, banks and financial service providers set up an ever widening array of subsidiaries there dedicated to exploiting the island's lenient fiscal and legal regimes. In that sense Curaçao provides a perfect example of the perceived advantages both of small dependent jurisdictions as home to financial services and of the core financial centres' creation of a new, dependent semi-periphery (Vlcek 2009; Palan 20I0). This last point, Curaçao's dependency, is highlighted by the fact that the Dutch government supported the island's OFC development as long as the Netherlands profited from it, at times even sacrificing tax income to corporate profits, but it thwarted Curaçao initiatives that threatened to harm home country interests. Our argument is organised as follows. We first discuss the various terms and definitions applied to OFCs and trace their origins. Section III then moves to the origins and initial development of Curaçao as an OFC during the I950s, followed in Sections IV and V by a discussion of its I970s and I980s heyday. Sections VI and VII analyse the reasons for Curaçao's decline as an OFC, followed by conclusions in Section VIII.

There is no academic consensus about what constitutes an OFC, because they differ widely in the kind of services offered (Zoromé 2007, p. 4). Moreover, not only have the terms to describe them changed over time, sometimes different authors label particular centres differently according to their understanding of their nature. The IMF, for instance, called Guernsey an OFC in 2000, whereas the economist Caroline Doggart found it a tax haven, a term dropped long ago by centres like Guernsey themselves because of the negative connotations (IMF 2000, p. 6; Doggart 2002, p. Io). The Netherlands, often and with some justification described as a tax haven as we will see below, does not regard itself as either a tax haven or an OFC. To sidestep the definition problem we use the commodious term OFC as defined by Palan et al., 'Jurisdictions that deliberately create legislation to ease transactions undertaken by people who are not resident in their domains, with a purpose of avoiding taxation and/or regulations, which they facilitate by providing a legally backed veil of secrecy to obscure the beneficiaries of those transactions' (Palan et al. 20 Io, p. 45).

For all their apparent differences OFCs share two key characteristics. They are as often as not located in small city-like states with close ties to large Western countries; and they were set up to boost local public revenue by attracting businesses and wealthy investors from elsewhere (Palan 20Io, p. I I I Palan et al. 20I0, pp. I24, I25). As a rule they do this by offering one or more special facilities such as low tax rates, low and flexible regulation, low supervision, and stringent confidentiality about client data. These facilities tend to be ringfenced, that is to say, only overseas corporations and individuals can use them, locals cannot. The idea to generate tax income from wealthy foreigners rather than locals is an old one. In I 856 Charles III of Monaco set up a casino there to generate revenue for his impoverished princedom, expecting 
to profit from the fact that roulette and other types of gambling were prohibited in neighbouring France. The prince was not disappointed. Buoyant casino income following a direct railway line to Nice (1868) and the prohibition of gambling in Germany (I 872) enabled him to abolish all direct taxes, which meant he could also avoid having to consult his subjects. A parliament was set up only in I9I I. This zero-tax concept combined with the agreeable climate to turn Monaco into the highly popular destination for HNWIs that it continues to be. Banks specialised in managing private portfolios followed in their wake (Godefroy and Lascoumes 2004, p. 29; Palan 2006, pp. I I 2-I 4).

Two US states pioneered a second concept to generate fiscal income, low regulation. In I 889 New Jersey introduced legislation specially designed to attract corporations away from New York on the other side of the Hudson River. Amended in I 896 and I899, this legislation freed corporations from the much more restrictive New York legislation about monopolies, mergers and takeovers, and trusts. As a result, the Standard Oil Trust, amongst many other companies, moved its formal seat to a New Jersey shell company, keeping its head office in New York (Palan et al. 20I0, pp. I09, IIO). Nearby Delaware quickly copied the low regulation concept to counter budget shortfalls. Following the introduction of highly permissive corporate legislation with hardly any oversight at all, the number of such companies registered there rose from I,400 in 1902 to 4,800 in I9I9. By that time more than 40 per cent of Delaware public revenue derived from registration duties and corporate taxation (Palan 2006, pp. IO I, IO2; Palan et al. 20 Io, pp. I IO-I I). The initial intention of these two states was attracting corporations with permissive legislation. However, the increasing divergence of state and local corporate taxes across the US opened opportunities for tax avoidance via shell companies. Delaware responded by lowering taxation on shell companies. Royalties paid to a Delaware company by its US subsidiaries, for instance, were made tax-free, though the company would still be liable to pay federal corporate tax. By cleverly routing their revenue flows via Delaware shells US companies could reduce their tax bill by I $5-24$ per cent (Palan et al. 20 Io, p. I Io; Dyreng et al. 20 I 3, pp. I I, I 2, 40). Shell companies offered the additional advantage of confidentiality, because the beneficial owner of the revenue flows could choose to remain hidden. By 20 I I Delaware counted more corporations than inhabitants, 945,000 against 898,000. Those corporations generated some $\$ 860$ million in duties and taxes, about 25 per cent of public revenue. ${ }^{1}$ The World Bank nurses grave concerns that the very high annual number of new legal entities in US, around ten times more than in all 4I tax haven jurisdictions combined, includes a large number of shell companies with hidden owners (Quillen and Hanrahan I993; Van der Does de Willebois et al. 20I I, p. 93; Vlcek 2017). ${ }^{2}$

1 The New York Times, I July 2012.

2 'How money laundering is poisoning American democracy', Financial Times, 29 Nov. 2019. 
The third concept common to OFCs, banking secrecy, was in fact fairly widespread at the beginning of the twentieth century. France, Britain, Germany and the US had it, amongst others, and the authorities there could lift it under certain conditions. By contrast, Switzerland attached such importance to banking secrecy that even the country's own tax authorities had difficulty in obtaining the information they required (Fehrenbach I966, pp. 48, 52, 56, 62, 63; Guex I999, pp. 6, 7). Political pressure from its neighbours caused the country to dig in during I930s. Wanting to track wealth hidden abroad, Germany and France tried to obtain Swiss account data. In I93 I Berlin sent over agents to get information by infiltrating bank staff. The following year Paris harassed local subsidiaries of Swiss banks, conducting police searches on their premises, instigating legal proceedings, sequestrating deposits and imprisoning bank officials (Guex I999, pp. I3-I6). When frightened foreign clients began withdrawing deposits from Switzerland, causing one Genevan bank to collapse, the government reacted by beefing up its banking secrecy (Palan 2009, p. I22). Under legislation adopted in I934 any violation became a criminal offence and prosecution of it mandatory whether or not the client affected filed a formal complaint, which, combined with the long-established practice of using numbered rather than named accounts, formed an effective shield for asset ownership. The Swiss banking secrecy law therefore served to facilitate tax evasion and not to protect Jewish assets from Nazi robbers, an erroneous assumption surfacing every now and then in the media. The law was an immediate success: Swiss banks' foreign deposits rose by 28 per cent over the following three years (Guex I999, p. 9; Palan 2009, p. I22). How much of that money was on the run from rising fascism and the threat of war and how much from tax authorities remains unknown. If the banking secrecy concept was therefore not invented by Switzerland, the country does hold the dubious honour of having invented anonymous accounts and maintaining the strictest form of secrecy (Guex I999, p. 9).

As early as the I920s and I930s countries discovered the competitive advantages of these three concepts. The Bahamas used the competitive advantages of its zero-tax regime to attract HNWIs from the US and Canada, followed by Bermuda (Hampton I996, pp. I7, 98; 'Sir Henry Tucker'; Palan et al. 2010, pp. I26, I27). Luxemburg introduced low taxes for holding companies, Switzerland added Delaware-style permissive corporate regulation to its attractions, and Liechtenstein copied the Swiss banking secrecy law (Assemblée Nationale 2000, p. I3; Palan 2009, p. 6; Palan et al. 20 Io, p. I I I). This was only the beginning.

\section{III}

Monaco, New Jersey and Delaware became tax havens really as a side effect of legislation introduced for other reasons. By contrast, Curaçao was designed as a tax haven by purposefully combining low taxation, low corporate regulation and confidentiality. Though the first steps were taken during the early I950s, it is worthwhile looking first at the prequel. 
The Dutch Caribbean islands were of no economic importance for the Netherlands or for Dutch corporations and investors until the discovery of oil in neighbouring Venezuela. Royal Dutch/Shell built a refinery on Curaçao to process the oil; an American company linked to Standard Oil did the same on Aruba. Coming on stream in I9I8, Shell's refinery grew into the company's biggest and the third biggest refinery in the world by 1938 (Van Soest I976, pp. I62-5; 1980, p. 23I; Hartog I993, p. 89; Jonker and Van Zanden 2007, pp. 447-9). When Royal Dutch scouted options for moving its legal domicile in case of war, the company therefore chose Curaçao, probably because the island's location between the US and Britain was considered more practical than the Dutch East Indies. In February I940 the Royal Dutch head of legal affairs A. S. Oppenheim established an office for the purpose in the Curaçao capital, Willemstad. Following the German attack on the Netherlands on Io May, he sat there and, aided by local notary Anton A. G. Smeets, signed the formal deed moving the Royal Dutch domicile from The Hague to his Curaçao office. By I942 some I 40 companies had followed suit and set up similar offices (Howarth and Jonker 2007, p. 29). ${ }^{3}$ These offices looked like shell companies, that is to say, they did no more than perform administrative corporate formalities such as convening and minuting annual general meetings. The board and business operations of the companies concerned remained abroad. However, the offices differed in purpose. They served to safeguard Dutch corporate assets from sequestration by the Allies and did not facilitate tax avoidance, paying the customary dues. ${ }^{4}$ Moreover, the offices were all wound up after the war. Therefore we do not, contrary to some of the literature, consider these shell companies as the start of Curaçao as an OFC (Whyte I985, p. 22; Haan I998, p. 297 n. 20; Tromp I999, p. I78; Palan et al. 2010, p. I30). ${ }^{5}$

The episode did have the effect, though, of putting Curaçao in the picture when in I950 the Nederlandsche Handel-Maatschappij (NHM) considered suitable locations for a trust office. This forerunner of ABN AMRO was the only Dutch bank to continue its international operations throughout the war from its New York office (De Graaf 20I2, pp. 296-7). A confidential board memo shows that the NHM board knew exactly what it wanted. ${ }^{6}$ Wealth taxes were driving capital away from the countries imposing them. The solution lay in shielding investors from what the memo termed 'fiscal difficulties' by inserting a third-country trust or holding company between them and their investments. Such companies proliferated in Luxemburg,

3 National Archives, The Hague (henceforth NL-HaNa), Ministry of Finance: financial attaché New York and Washington, I940-I974, collection no. 2.08.75, inv. no. I54, letter I I May I942 with a list of companies.

4 Parliamentary Papers, the Netherlands, Second Chamber I939/40, no. I75-6, pp. I 2 and I3; idem First Chamber I939/40 I75, final report of the Reporting Commission, ministerial reply, p. 8.

5 Financial Times, 24 Nov. I982.

6 NL-HaNA, NHM, 2.20.o I, inv. no. I3887, confidential memo 'Trustmaatschappij Curaçao', is May I950. 
but the bank needed something closer to America for serving the growing needs of Dutch investors in the US: a location with a stable jurisdiction, preferably a small one so it was easier to get things done. Curaçao was ideally suited to become a safe haven, the memo concluded, though as yet the island lacked the necessary expertise and dedicated legal framework. ${ }^{7}$ In September I950 the NHM sent a high-ranking official, W. van Ravesteyn, to Curaçao to chart the possibilities and options.

Once there, Van Ravesteyn met with the island's governor, politicians, representatives of the three local banks, the Chamber of Commerce, and with the notary Anton Smeets. The following month Van Ravesteyn, convinced by these talks that the local government was willing to pass the legislation which the NHM wanted, formally set up the Nederlandsche Handel-Maatschappij Trustkantoor Curaçao, the island's first unit dedicated to tax avoidance. ${ }^{8}$ It is therefore incorrect to credit Smeets with having taken the initiative to launch the OFC, as most of the literature does. Though then and later he showed himself to be highly enterprising, imaginative and active in promoting all kinds of legal and financial services, the initiative clearly came from the Dutch bank and not from him (Hagen I989, p. I 59; Metry 2006, p. 438).

\section{IV}

That said, the NHM initiative succeeded because the local authorities fully understood how to use fiscal incentives for attracting international business. By I950 they had already been at it for some time. When in I9 I 5 Royal Dutch/Shell made building its refinery conditional on obtaining exemption from customs duties, the Curaçao governor urged the Colonial Council to grant the Group fiscal advantages 'of the utmost generosity'. 'Six years later the governor succeeded in preventing the Council from repealing the incentives using arguments supplied by Shell (Van Soest 1976, p. I75). As it was, the money flowed in anyway. Buoyed up by income from oil refining and allied business such as shipping, public revenue rose rapidly, rendering Curaçao entirely self-supporting from I928 (Van Soest I978, p. 225; I980, p. 234).

The Curaçao authorities proved similarly alert to new opportunities following the NHM initiative. As early as April I95 I the acting governor submitted draft legislation to the parliament granting shell companies a 90 per cent tax exemption on dividends received. ${ }^{10}$ We therefore date the beginning of Curaçao as an OFC to that first purposeful legislation in April I95 I, rather than May I940, as the literature often does (Van Soest I978, p. 339; Lang 200I, pp. I32-3; Metry 2006, p. 436; Boise and Morriss 2009, p. 405). In September 1952 the business tax for shell companies was

\footnotetext{
7 Ibid.; a perfect illustration of the argument of Palan (20 I0).

8 NL-HaNA, NHM, 2.20.o I, inv. no. I3 387 , report about the Curaçao talks, I 8 Oct. I950.

9 Colonial Council, cover statement of the refinery tax decree in Amigoe di Curaçao, 20 Mar. I9I 5.

10 Netherlands Antilles Parliament I950-I95I-47, presentation, draft decree and cover statement.
} 
reduced to $2.4-3$ per cent, one-tenth of the normal rate. That last measure was ringfenced, the Antillean government fearing excessive loss of revenue if it were also to apply to locals. ${ }^{11}$ The notary Anton Smeets, a prominent member of the local elite with a string of official functions to his name, presumably helped to frame these regulations and smooth their passage. Born in Rotterdam, Smeets (1909-97) was appointed as Curaçao notary in I938, where he quickly became a prominent member of society and active in many semi-official and official public functions (Metry 2006, p. 438). He already possessed wide experience in running shell companies, having handled 53 of the 140 company domicile moves during World War II. ${ }^{12}$ The contemporary jibe that, during the I950s, Curaçao financial expertise amounted to 'three donkeys and six dinosaurs' was thus both supercilious and untrue (De Jong 20I8, p. I9).

As it happened, Curaçao's first, tentative steps towards forming an OFC failed to have much effect. In I95I two local banks, Edwards, Henriquez \& Co. and Maduro \& Curiel's Bank, set up trust companies, after which NHM took a half stake in the former. The following year two Dutch private banking firms, Heldring \& Pierson and Pierson \& Co., opened a joint trust office and in I953 Smeets set up a trust company, a forerunner of his later and highly successful Curaçao International Trust Company (Citco) (Van Beurden 20I8, p. I Io). Despite the NHM's dedicated efforts to drum up interest in the new opportunities in New York, business began growing only during the later I950s as a result of purposeful, concerted steps taken by the Antillian government to increase the attractiveness of the islands' financial offshore opportunities for investors elsewhere. Using Curaçao-based fiscal constructions only made economic sense if the fiscal advantages outweighed the constructions' cost. To achieve that the island government needed to find countries willing to conclude tax treaties with favourable rates on money flowing into shell companies so that investors paid little or no tax at source and a pittance on Curaçao. The authorities prioritised negotiations with the US, Britain and the Netherlands, regarded as the most promising targets.

For those talks Curaçao needed and gained Dutch support. An Interim Agreement concluded in I950-I and enshrined four years later in the Statute of the Kingdom of the Netherlands redefined the legal and administrative ties within the realm. The Antilles became largely autonomous while retaining close ties with the Netherlands. Those ties were of vital importance for Curaçao as an OFC. They lent its service industry the necessary aura of reliability, notably because the High Court in The Hague remained the realm's court of highest instance. Moreover, Curaçao could rely on the Dutch Ministry of Foreign Affairs for negotiating tax treaties with third countries.

11 Netherlands Antilles Parliament I952-I953-39, cover statement and preliminary report.

12 NL-HaNA, Mnistry of Finance 2.08.75, inv. no. I 54, letter I I May I942. 
In June I95 I the Antillian government formally requested, more or less at the same time as the first legislation on shell companies, to be permitted to join to the tax treaty between the US and the Netherlands, concluded three years before. Talks were conducted in Washington through the Dutch embassy there, and closely followed by the Ministry of Finance back in The Hague and by Dutch businesses like the auditing firm Kraayenhof, later a constituent member of KPMG, and the Anglo-Dutch multinational Unilever. When negotiations appeared to drag Unilever expressed its anxiety to the embassy. ${ }^{13}$ In 1955 the two sides agreed. Royalty and interest payments to Curaçao shell companies were exempted from the 30 per cent US tax at source and the rate for dividend payments was reduced to I 5 per cent. Unilever's New York representative immediately left for Willemstad to set up a subsidiary of the company's finance division, Unitas. ${ }^{14}$ And that marked only the beginning. The number of shell companies more than doubled from I80 in 1956 to 400 the folllowing year (Van Beurden 2018, p. I23, graph 3). Within five years the US government regretted having allowed the Antilles to join and wanted to terminate the treaty or negotiate a fundamental revision, arguing that non-residents of the Antilles profited from treaty advantages to which they had no right. ${ }^{15}$

Meanwhile, in I952, the Antilles had also asked to join the tax treaty between the Netherlands and the United Kingdom; five years later the treaty was signed, coming into force retrospectively in I953. The Dutch Ministry of Finance was at the heart of the bilateral treaty talks and fully aware of corporate fiscal desiderata. Therefore it knew the stakes when in 1954 the Antilles asked for negotiations about a new fiscal framework between the two countries. ${ }^{16}$ Nor did the Antillean government beat about the bush, demanding exemption from taxation at source for dividends sent from the Netherlands to Curaçao. ${ }^{17}$ The Dutch negotiators firmly resisted this demand because 'the Antilles' far-reaching fiscal facilities ... would open up a tax drain from the Netherlands' and were prepared only to accept it if The Hague obtained the right to unilaterally end the agreement if the tax drain assumed 'intolerable proportions'. ${ }^{18}$ This the Antillean delegation refused for fear of the US reaction if the Netherlands, of all countries, insisted on having an emergency brake. The Dutch

13 NL-HaNA, Fin/IFZ, 2.08.5229, inv. no. 480, letters 20 Jan. I953, 28 Jan. I954 and Io Feb. I954 to the Ministry of Finance in The Hague.

14 NL-HaNA, Fin/IFZ, 2.08.5229, inv. no. 480, overview of 30 Dec. I955 with annex to the Ministry of Finance.

15 NL-HaNA, Fin/IFZ, 2.08.5229, inv. no. 520, telex I2 Dec. I96I to the Washington embassy; NL-HaNA, Fin/IFZ, 2.08.5229, inv. no. 480, draft letter to the US secretary of state, an annex to a letter of I4 May 1962 to the minister of foreign affairs.

16 NL-HaNA, Kabinet Vice-PM/KabSNA, 2.I0.4I, inv. no. I29I, letter I2 Oct. I954 to the minister for the realm overseas.

17 NL-HaNA, Kabinet Vice-PM/ KabSNA, 2.IO.4I, inv. no.I29I, annex to letter I2 Oct. I954 to the minister for the realm overseas.

18 NL-HaNA, Kabinet Vice-PM/KabSNA, 2.I0.4I, inv. no. I29I, p. 3 in the annex concerning talks in Mar. I957 to the letter of I 8 Apr. I957 to the minister for the realm overseas. 
negotiators countered the Antillean objection by subtly pointing out that 'more or less paper constructions like these investment companies existed only on sufferance'. The American tax authorities were 'no fools'; if they had refrained from taking steps they simply saw no need as yet. ${ }^{19}$ After more than a decade of negotiations the two sides reached a compromise with the 1965 Belastingregeling Koninkrijk (BRK, Tax Arrangement for the Realm), which gave the Antilles the exemption of dividend taxes at source and the Netherlands its emergency brake. ${ }^{20}$ Though the intolerable proportions' remained undefined, the emergency brake was to prove useful subsequently. In short, the Dutch government, by accepting the BRK, willingly and knowingly created a conduit for tax avoidance in its own country.

From the available documentation we cannot make out to what extent Dutch corporations and financial institutions influenced this outcome. Representatives of multinational corporations Unilever, Royal Dutch Shell, Philips and C\&A freely vented their wishes to the Dutch Ministry of Finance, solicited or unsolicited and directly or through banks like the NHM. They also exerted pressure on the Curaçao government, though not always successfully. A draft law to exempt non-residents from succession tax was ultimately dropped despite strong pressure from the NHM acting on behalf of the clothing concern C\&A (Van Beurden 20I8, pp. 87-8). However, a closer look at the BRK's ramifications strongly suggests that Dutch corporations and financial institutions must have helped to shape it, because the treaty's tax exemption for dividend payments to Curaçao also opened up fresh corporate tax avoidance opportunities via the Netherlands. Multinationals could now choose to concentrate dividend or royalty payments from subsidiaries elsewhere in an Amsterdam shell company and from there send the money tax-free to Curaçao for further low-duty uses. The advantages of such constructions could be considerable. During the I960s and I970s a Dutch company, V, earning I00,000 guilders patent royalties from Sweden, for instance, would have to pay 48 per cent corporate tax over that income if received directly, so would be left with 52,000 guilders (see Figure I, adapted from De Kam I977a, pp. 65-6). Company V would be far better off setting up a Swiss subsidiary holding the patent and have royalties taxed there at a rate of 8 per cent. The Swiss subsidiary could then pass the royalties on to a Dutch shell company (tax-free on the basis of the treaty between the two countries), which would send them to a Curaçao shell (tax-free under Dutch law), where they would be taxed at the offshore rate of, say, 3 per cent. Result: company $\mathrm{V}$ receives 89,240 guilders, a gain of 37,240 guilders gross, not counting the administrative costs of setting up and running the three shells.

The Dutch government rendered options like this possible and all the more attractive by purposefully building the widest possible array of bilateral tax treaties with low mutual taxes on dividends and royalties (De Kam I977a; Van Dijk et al. 2006).

19 NL-HaNA, Fin/IFZ, 2.08.5229, inv. no. 97, report of talks 26 Sep. I960.

20 Parliamentary Papers, the Netherlands, Second Chamber I962/63, 7I 8 I, no. 2. 

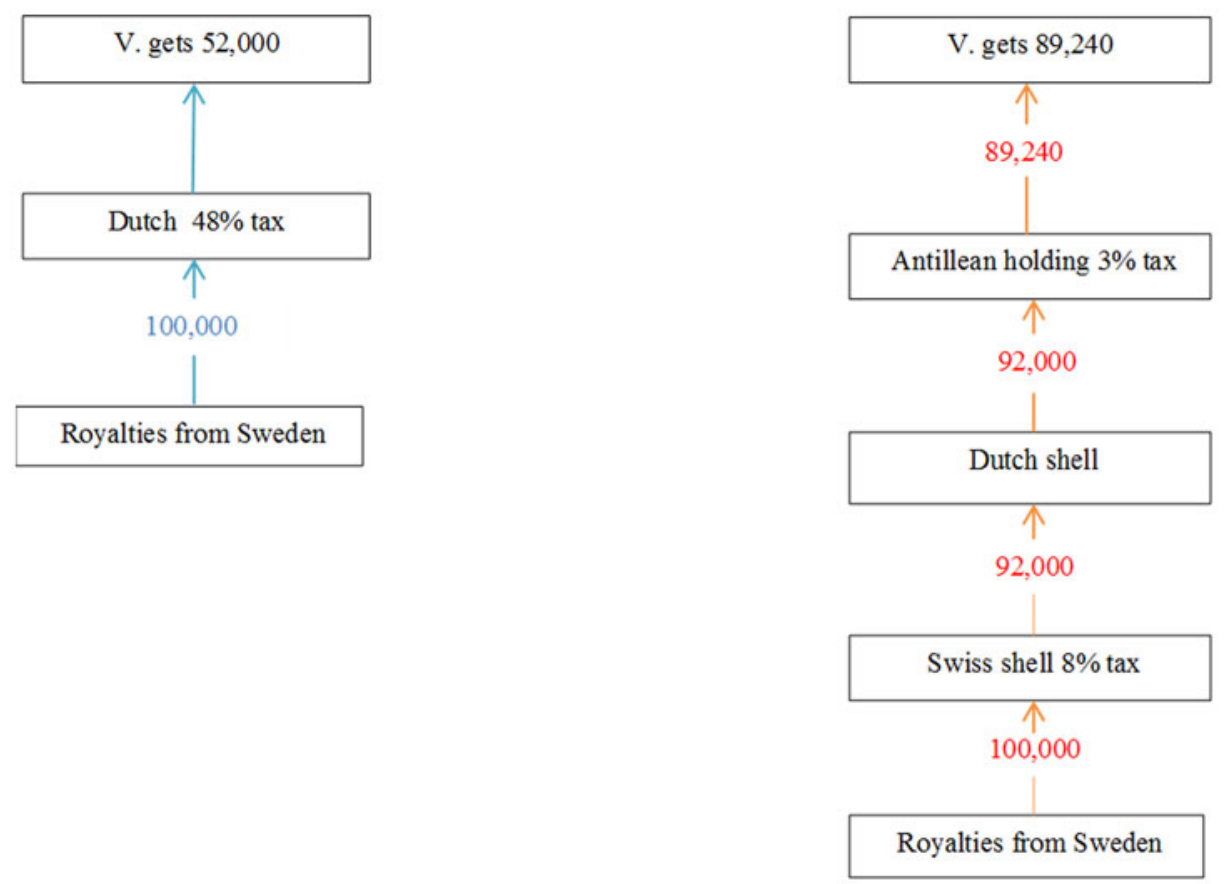

Figure I. Stylized example of potential tax gains by rerouting royalty earnings abroad

Funnelling a growing flow of money from around the world via the Netherlands to Curaçao, those treaties generated tax revenue and income for the Dutch legal, financial and accounting sector. Thus the BRK not only boosted Curaçao as an OFC, but laid the groundwork for the Netherlands as a tax haven as well.

\section{V}

During the I950s the Curaçao OFC was still seen as something to be treated with circumspection. In I954 Royal Dutch Shell criticised a draft law on patent holding companies, conceived at the special request of Philips and promoted by the NHM, as threatening to turn Curaçao into a reservoir for all kinds of shady international dealings. ${ }^{21}$ Two years later the member of the Antilles parliament Ch. Voges warned against granting exemptions too freely since this would promote tax evasion elsewhere and harm Curaçao's good reputation. He spoke out again in $1958 .^{22}$

The OFC's growth opportunities elbowed that circumspection aside. The Antillean government systematically expanded the available facilities to attract

21 NL-HaNA, NHM, 2.20.0I, inv. no. I3877, letter 30 Nov. I954 to the NHM trust office in Willemstad.

22 Netherlands Antilles Parliament I955-6 minutes, no. I2, p. 353, and I957-8 minutes, no. 9, p. 766. 
customers from all over the world. Key steps in that process were a revised law on patent holding companies (I957), long-term legal guarantees of shell company tax rates (I958), individual and confidential tax rulings for special arrangements proposed by offshore companies (1967), and low entry requirements and an exemption from supervision for offshore banks (I972) (Van Beurden 201 8, pp. 85, 88-9, IO6; the theoretical dimension of dedicated legislation is discussed in Hudson I998). Tax rulings and the absence of offshore banking supervision worked hand-in-glove with a policy of utter discretion. The Antilles government fully understood the importance of shielding the identity of beneficial owners, as did Delaware, and it adopted a selfimposed, informal banking secrecy regime, not a formalised, legal one like the one the Bahamas copied from Switzerland in I965 (Hampton I996, pp. I7, 98). Banks and trust companies gave no information unless ordered to do so by an Antillean court. Even a simple requirement for offshore banks to file notice of unusual transactions foundered on strong objections from the sector. ${ }^{23}$ Information requests from the Dutch tax authorities were put off for as long as possible, requests from other countries ignored unless the customers concerned agreed with their being answered (Beers I980, p. 85).

Then again, as a rule obtaining information about the owner or beneficiary of a given shell company's assets was practically impossible, because bearer shares or the stacking of shell companies provided efficient shields. A finance instrument launched by the Dutch bank Pierson, Heldring \& Pierson (PHP) in I 969 widened the available camouflage options. The bank arranged a share issue for Royal Dutch in the form of so-called Curaçao Depository Receipts or CDRs, bearer certificates representing Royal Dutch shares taken up and held in trust by PHP. This type of certificates, common in the Netherlands since the late eighteenth century, really embodied the dividend right split off from the underlying shares. Certificate holders thus received the company's dividends without being traceable via its shareholder register. CDRs were also exempt from the Dutch stamp tax, so cheaper to issue. Following the Royal Dutch issue PHP sold the formula to various international corporations, including the notorious fraudster Bernie Cornfeld's Investor Overseas Services, Leasco and the German multinational BASF. ${ }^{24}$

Opening what became known as the Antilles Route or the Antillean Window, these initiatives boosted both the number of shell companies and public revenue from profit taxes, slowly but steadily at first, then very rapidly, peaking during the mid I980s and then declining (Figure 2). In I969, the earliest figure available, I,350 offshore companies generated 8 million Antillean guilders (NAf) of profit tax, I6 per cent of Curaçao public revenue (Van Beurden 20i8, pp. I23, I27).

23 Netherlands Antilles Parliament I970-I, I3, Preliminary report.

${ }^{24}$ See specimens on www.google.com $/$ search?q $=$ cura $\% C_{3} \% A 7 a o+$ depositary + receipts\&rlz $={ }_{\mathrm{I}} \mathrm{CICHBF}_{\mathrm{I}}$

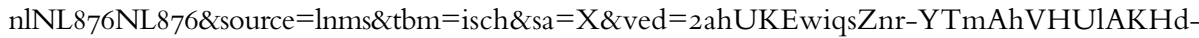
BWBAMQ_AUoAnoECAsQBA\&biw $=$ I $536 \&$ bih $=760$ (accessed 26 November 20 I9). 


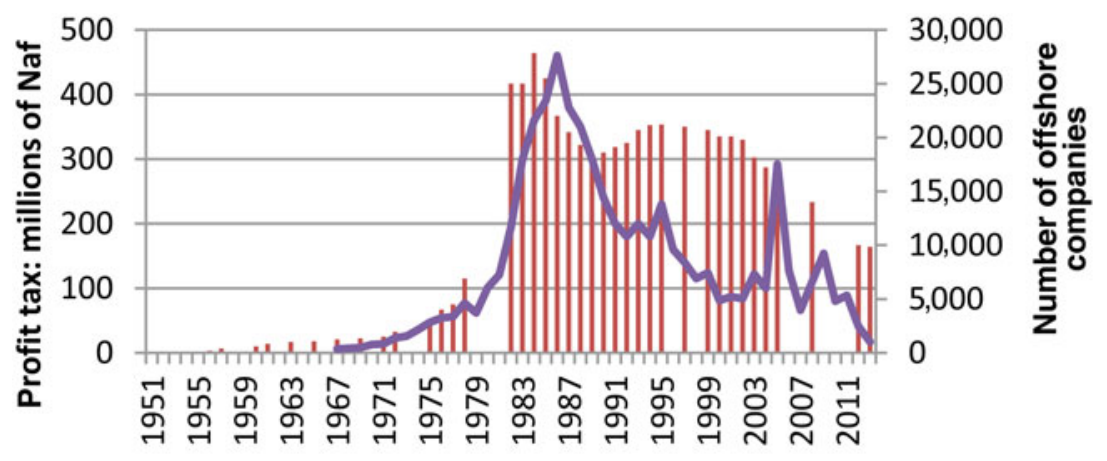

offsh. C.

Figure 2. The number of offshore companies and public revenue from profit tax on Curaçao, I95I-20I 3

Source: Van Beurden 2018, p. 344.

The number of companies rose to 2,900 in 1975 and over 27,850 ten years later (Van Beurden 20I 8, pp. I25, I 84). Profit tax income leaped in tandem, to 47 million NAf in 1975 and 390 million by 1985 , the low rates being more than compensated by the high volumes. In that year its share in Curaçao public revenue, hovering around $20-25$ per cent until the early I980s, peaked at an astounding 50 per cent before gliding gently back to its former level (Figure 3).

A variety of factors can be identified behind this growth, some linked to the ties between Curaçao and the Netherlands, some linked to international developments. First, Dutch investment funds, the enterprising Robeco of Rotterdam foremost amongst them, found more and more ways to have their clients profit from the Curaçao facilities. Mutual funds from other countries followed hard on their heels (Van Beurden 20I 8, pp. I I7-I8). Second, Dutch and other corporations increasingly discovered the advantages of routing revenue flows via the Netherlands and Curaçao; the flow of dividends from the former to the latter, I 46 million guilders in I978, rose to I.8 billion Dutch guilders in I98I and even I2 billion in I985, only to fall back sharply following a treaty change to be discussed below (Figure 4) (Van Beurden 20I 8 , p. I 38 table I 5 ).

Those two big inflows and the shell companies that fed on them were managed by subsidiaries, trust companies, and offshore banks set up by Dutch banks like ABN, AMRO, NMB, Hollandsche Bank Unie, F. van Lanschot Bankiers, Mees \& Hope, the Nationale Handelsbank, Pierson, Heldring \& Pierson and Slavenburg's Bank. All main auditing and tax consultancy firms such as Van Dien, Van Uden, Besançon, Koppenberg \& Co., Klynveld, Kraayenhof \& Co., Moret \& Oudheusden and Loyens \& Volkmaars, also had Curaçao subsidiaries (Van Beurden 20I8, pp. I08, II4, II5). 


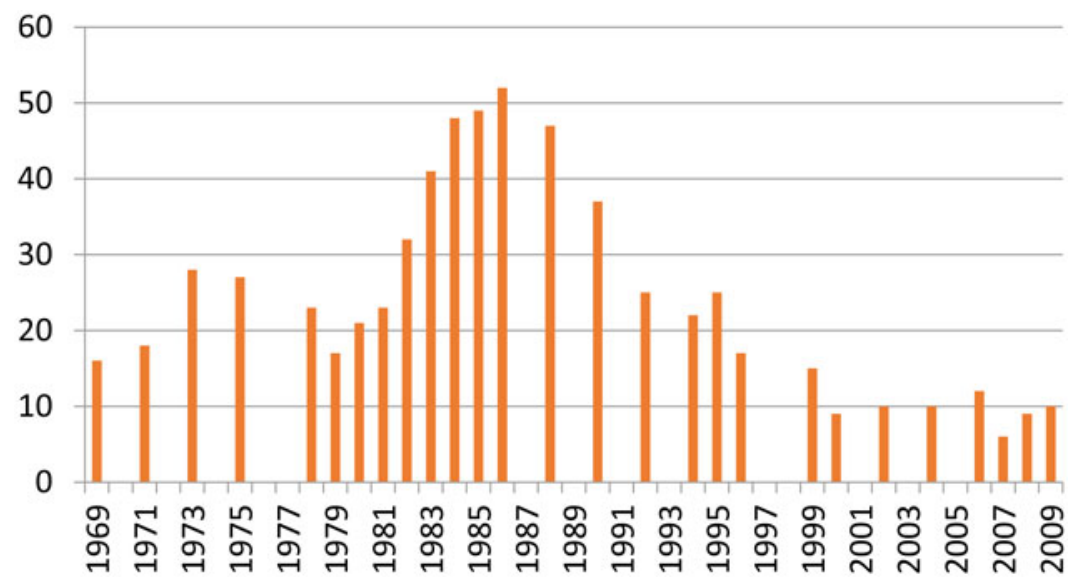

Figure 3. The profit tax share in total Curaçao government income, I969-2009 (\%) Source: Van Beurden 2018, pp. I27, I85, 245, 323.

From the mid I96os the Curaçao offshore sector internationalised and diversified when the Eurodollar and Eurobond markets moved from Europe to the Caribbean, notably to the Bahamas, which became the second largest Eurodollar market after London (Roberts I994, p. xx; Palan et al. 20 Io, p. I 28). Curaçao profited from US corporations setting up finance subsidiaries there to borrow in Eurodollars and profit from a special tax ruling, which allowed corporations to offset interest paid as costs against interest payments received from the US and granted them a fictive profit rate on their Curaçao subsidiaries of only i per cent of money borrowed (Mathieson and Laudicina I982, p. 5; De Kam I983). In I969 such US corporate finance subsidiaries borrowed some US $\$ 800$ million on the Eurodollar market via Curaçao, I.I billion in 1978 and I0.3 billion four years later (Papke 2000, pp. 300, $30 \mathrm{I}) .^{25}$ Eurodollar operations also boosted the number of offshore banks, the Bahamas already counting 200 such banks in I967. The Curaçao number remained more modest, rising from two in 1969 to 53 in I989, by which time Dutch banks were heavily outnumbered (Table I). The foreign banks in that last year included I6 from Venezuela, three from the US, and two each from Canada, France, Italy and Switzerland, though by then the two UK banks present in I980 had left.

Another aspect of Curaçao business deserves notice. During its I970s and early I980s heyday the diversity of services widened considerably with the arrival of mutual funds, real estate companies and insurance companies. As a result, the island offered as full an array of specialised financial, fiscal and legal services as any OFC, and perhaps fuller than most. A strength during its heyday, this would turn into a weakness when the tide turned, preventing as it did a consensus about the best

25 NL-HaNA, NHM, 2.20.0I, inv. no. I3883, letter I7 Jan. I969 to the NHM trust company in Willemstad and letter 25 June I970 to Philip Morris Inc., New York. 


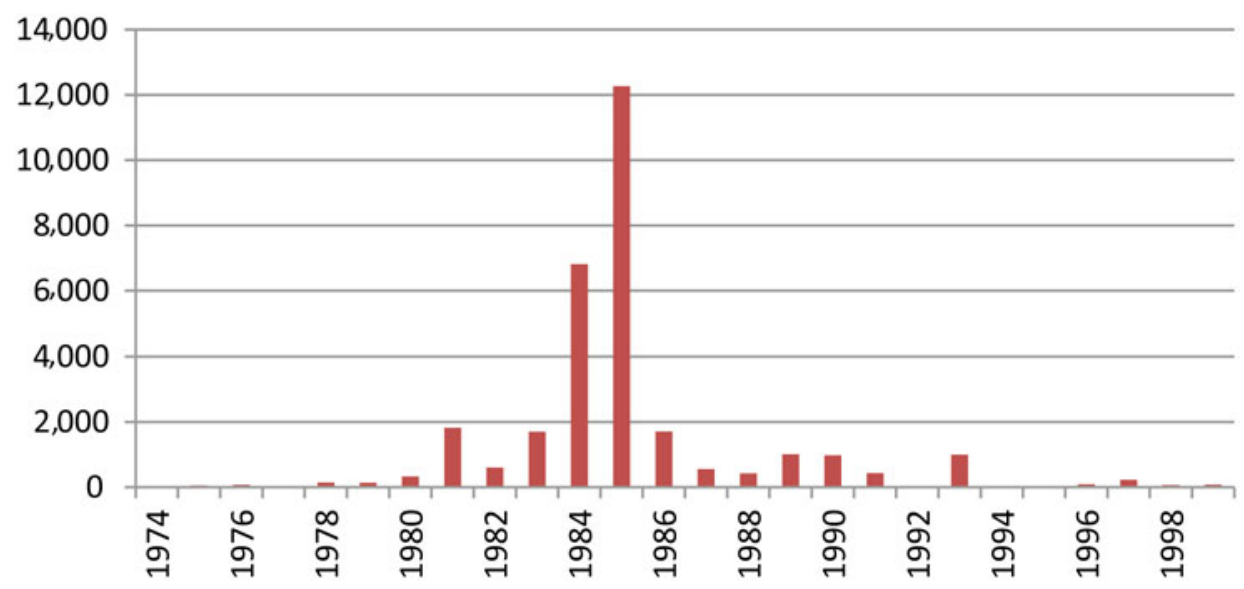

Figure 4. Dividends from the Netherlands to Curaçao (Nfl mln), I974-99

Source: Van Beurden 2018, p. 345.

course of action to stem that tide. Finally, we have to keep in mind that Curaçao continued to lag behind rival OFCs in the region like the Bahamas, the Cayman Islands, or the British Virgin Islands (see Appendix).

All that economic activity generated very little local employment, labour intensity being low. A typical trust company office scene, drawn from life, underlines this (adapted from Kagie I982, pp. I05-6). Two staff members sit at a desk. One of them opens the annual general meeting of shell company A, takes the chair and appoints his colleague as secretary. They sign the list of shareholders present for the proxies they hold, leading the chairman to conclude that the company's entire capital is represented. The two then tick off the points on the agenda, after which the chairman closes the meeting. This scene, all ten minutes of it, took place on 8 March 1979 and characterises the bulk of the financial offshore work, that is to say, endless formal, administrative processes to manage flows of money, repetitive, fairly simple and requiring very little manpower. At its mid I980s peak the offshore sector provided no more than about 3 per cent of total Curaçao employment or I, 500 direct jobs, some I4 per cent of which were taken by expats (Hagen I989, pp. I57, I58; Van Beurden 2018, p. I88). The sector remained an island on the island with no discernible effect on the stubbornly high unemployment rate of I 5-20 per cent (Haan I998, p. I60 figure 5.I).

Though the spin-offs were therefore very limited, a clear consensus existed that the financial offshore needed further expansion to keep the bread of heaven, the flood of government revenues, coming in. Aruba's leading political party, the Movimiento Electoral di Pueblo (MEP), campaigned on turning the island into a blossoming tax haven like Curaçao in the run-up to the 1979 elections. ${ }^{26}$ The Netherlands 
Table I. The number of Curaçao offshore banks, 1969-89

\begin{tabular}{lcccc}
\hline \hline & I969 & I975 & I980 & I989 \\
\hline Offshore banks & 2 & I4 & 3 I & 53 \\
Of which Dutch & 2 & 7 & I4 & I7 \\
\hline \hline
\end{tabular}

Sources: Beers I980, pp. 78, 79, I05-I2; Hagen I989, pp. II3, I I4; Van Beurden 2018, pp. I25, I77, I84, 236.

fully agreed. An Experts' Commission set up jointly by the Dutch and Antillean governments to study the islands' economic future reported that same year and recommended a further expansion of commercial services there, including the financial offshore (Joint Commission of Experts 1979, pp. I5, 31).

However, just at that time the first cracks had already appeared in the success formula. As we have seen above, the US regretted having allowed the Antilles to join the Dutch-American tax treaty as early as I960, only five years after having agreed to it. The US government disliked the ultralow Antillean tax rate and the treaty's abuse by non-residents, which caused an estimated US $\$ 86$ million tax loss. ${ }^{27}$ Washington was also anxious to prevent development aid given to South American countries from being fraudulently syphoned back into lucrative US investment via Curaçao shell companies. ${ }^{28}$ In 1962 Washington gave notice of the treaty's imminent cancellation unless the Antillean government agreed to fundamental changes.

Supported by lawyers and a bank in New York and by the NHM trust company back in Curaçao, the Antillean government chose a dilatory defence policy sustained with disingenuous arguments. Though knowing the amounts coming in, their own gain from that, and thus the likely tax loss in the US, the Antilles belittled the issues raised. The American tax loss did not exceed US $\$ 3-4$ million for a Curaçao gain of only US\$I million. Prodding the US concern about regional political stability following the I959 Cuban revolution, the Antillean government, knowing full well that US \$I million represented no more than 3 per cent of public revenue, argued that a loss of public revenue threatened to bring radical political parties to power. Finally, no South American citizens used local shell companies, an assertion the Antilles could not back up given the customary use of bearer shares. It came as no surprise that the US government cut through the Antilles' weak position and put to them a simple

27 Van Beurden (201 8, p. 97), an estimate based on Antilles data putting the total of US investments via shell companies for 1960 at US\$573 million taxed at I 5 per cent.

${ }^{28}$ NL-HaNA, Fin/IFZ, 2.08.5229, inv. no. 520: memorandum 30 Mar. I962, pp. 8 , 9. 
choice: if they did not immediately accept the proposed changes the treaty would be cancelled. This worked: the revised treaty came into force on I January I965. Henceforth, the US tax advantages would only apply to dividends, interest, and royalties paid to companies entirely owned by residents on the Antilles and in the Netherlands and by corporations in the Netherlands (Matthieson and Laudicina I982, pp. 67-8; Van Beurden 20I8, pp. 95-I00). The sector quickly found a loophole, which enabled them to carry on as before. Companies now needed an official document issued by the Antillian fiscal authorities declaring them entitled to the US tax advantages in conformity with the new regulations. These documents were issued freely even though the authorities were in no position to check who owned the companies concerned (Van Beurden 2018, p. IOO).

As a result, the Antillean Window remained wide open for everybody and for a considerable time to come. It was only in I979 that the US government again requested treaty revision, the start of negotiations that were to last nine years before foundering on the Antillean government's stubborn and ill-advised insistence on the need for absolute confidentiality of client data. ${ }^{29}$ This time two issues inspired the request for revision. During the I970s a cheap dollar and high returns boosted inward investment in US real estate, raising public concerns there about foreign ownership notably of farm land. ${ }^{30}$ A substantial part of these investments was made through Curaçao property and finance companies that profited from the American and the Antillean tax exemptions on real estate capital gains (Smeets I985, pp. 24I-3). In addition, the US had found out that the Antilles with their 230,000 inhabitants received no less than $\mathrm{I} 3$ per cent of all interest paid by US borrowers to lenders abroad in 1978 (Gordon I98 I, p. I5I). Therefore a large part of that money simply had to be pocketed by parties not covered by the tax treaty's provisions. Wanting to eliminate treaty shopping by third parties, Washington once again requested access to information about the owners or beneficiaries of shell companies.

Curaçao considered confidentiality crucial for its services, but, realising it stood no chance of keeping it if Washington wanted it scrapped, decided anew to play along in the hope of profiting from the status quo for as long as possible. Accordingly, the Antillean negotiators soft-pedalled and once again emphasised the importance of public revenue derived from a blossoming OFC for maintaining social stability in the face of stubborn high unemployment. The Dutch government firmly supported that particular argument. If this approach succeeded in extending the status quo for another nine years this was due less to Antillean ingenuity or insistence in arguing their case than to the dynamics of American decision making. Having made its intentions clear, Washington ran into strong opposition from heavy users of the Antillean

NL-HaNA, Diplomatic Embassies USA, 2.05.263, inv. no. 76, telex 27 June 1979 to the Antillean government.

30 NL-HaNA, Diplomatic Embassies USA, 2.05.263, inv. no. 76, letter 29 Nov. I979 to the Antillean prime minister. 
Window. Curaçao possessed a practical monopoly on issuing Eurobonds for US corporations, which peaked at US\$I0.3 billion in I982 (Van Beurden 20 I 8, pp. I 57-8). ${ }^{31}$ Two years later pressure on the talks eased when Congress abolished the 30 per cent withholding tax on interest payments, at a stroke rendering superfluous the numerous Antillean shell companies that had existed to circumvent that tax. ${ }^{32}$ When in 1986 the two sides had finally reached agreement, Congress passed a Tax Reform Bill, which prompted the Antilles government to ask for a reopening of the talks. ${ }^{33}$ Supported by repeated interventions from the Dutch minister for foreign affairs directly with the State Department, the Antillean government attempted to use the opportunity to negotiate better terms, only to be told that the US government saw no need to support the Curaçao fiscal industry. In May I987, Washington set an ultimatum: unless the Antilles accepted the draft treaty with its clear rules about information exchange, the existing treaty would be terminated. ${ }^{34}$ Curaçao opinion was divided. The sectoral organisations rejected the draft, hoping against hope that it would still be possible to negotiate better conditions. Some banks were in favour because any treaty with the US enhanced their international status. ${ }^{35}$ They could point to the readiness with which Barbados had negotiated a new treaty with the US following termination of the existing one in I983. Within I 8 months the two sides had agreed and the new treaty, in force since February 1986, had done Barbados no harm at all. ${ }^{36}$

In the end the Antillean government rejected the draft treaty, after which the US cancelled the old one as per January I988. ${ }^{37}$ Together with the 30 per cent withholding tax on interest payments this treaty had been the cornerstone of the Curaçao OFC, so the termination of the former and the abolition of the latter marked the end of more than 20 years of explosive growth. The number of offshore companies, public income from profit taxes and from foreign exchange payments all dropped sharply, perked up a bit again during the I990s, but that was temporary: a firm base for renewed growth had disappeared. Within just a few years Curaçao regretted having turned down the US draft, all the more so since Barbados continued to flourish with its revised treaty. Twice the Antillean government attempted in vain to get a new treaty: Curaçao had simply missed the boat. Subsequently, both Britain and Denmark also terminated their tax treaties with Curaçao. The island found it difficult to adjust. Disagreement between the various subsectors prevented it from charting a new

31

Herald Tribune, 30 Nov. 1982.

Het Financieele Dagblad, 7 Nov. 1984.

3 Amigoe, I7 July 1986.

34 Amigoe, 29 May 1987; Het Financieele Dagblad, 30 May and I June I987.

35 Amigoe, 6 and I 3 June I987; Het Financieele Dagblad, 30 May and I June 1987.

36 NL-HaNA, Diplomatic Embassies USA, 2.05.263, inv. no. 79, letter with annexes 5 July 1983 to the Antillean minister of finance; Global Forum on Transparency, 'List of Agreements', consulted on 3 I Aug. 2016.

37 Amigoe, 30 June 1987. 
course, causing Curaçao to lose ground to rival OFCs like the Cayman Islands, the British Virgin Islands and Bermuda (Van Beurden 20I8, pp. I73, 239-44). Adjustment was to prove increasingly hard in time to come.

\section{II}

During the late I970s public opinion about OFCS began to change. At the beginning of the decade a Dutch newspaper could still describe the Curaçao offshore as 'a very curious source of revenues', but towards its end newspapers began criticising corporations from the Netherlands and abroad avoiding taxation by funnelling dividends and royalties to Curaçao. ${ }^{38}$ Dutch members of parliament also started raising questions about both Curaçao and the Netherlands' own involvement in tax evasion. ${ }^{39}$ Prompted by complaints from tax treaty partner countries, the Ministry of Finance took steps to curtail flows of money bypassing the Dutch tax system. Though it had a minor effect on the Curaçao offshore compared to the huge impact of the US interest tax abolition and treaty cancellation, this policy change stung Antilleans, probably because they knew that the Netherlands continued to profit alone from arrangements once set up for mutual benefit. ${ }^{40}$

The first change was small and innocuous. For income tax purposes foreign mutual funds were assumed to yield a fictive 3.6 per cent. In I979 the government, arguing real yields to be rather higher as a rule, raised this to 6 per cent; the Curaçao mutual funds and the Antillean government were up in arms over the increase. The funds complained bitterly about their business being killed, the government cried foul because the fictive yield raise had been decided without prior consultation, threatened 375 offshore companies and an income loss of I 5 million Antillean guilders, and risked sparking serious social unrest. ${ }^{41}$ These claims were ludicrously exaggerated. The mutual funds' return to investors, though reduced, remained very attractive compared to alternatives. To the best of our knowledge none of the funds left Curaçao or liquidated due to the change; Rorento, a fund that had shouted loudest about being driven out of business, remained on the island until 20I3 (Van Beurden 2018, pp. I32, I33, I 35 , I36). With the attraction of investing via the Antilles diminished but still attractive, the tax income which it generated remained unaffected. Finally, at most an estimated 25 jobs on Curaçao depended on Dutch investors out of total offshore employment of 460 people and a labour force of 45,000 (Van Beurden 2018, p. I35). The Dutch Parliament did consider, though, that the Antilles should have

38 Utrechts Nieuwsblad, 7 Apr. I970; De Kam I977b.

39 Parliamentary Papers, the Netherlands, Second Chamber I979-I980, no. I5 5I7-6, p. 3 and no. Is 975-I, p. 5I; idem, Second Chamber I979-I980, Transactions (Committee Meeting) 3 Dec. I979, p. 524 and I3 Feb. I980, pp. 2954, 2955.

40 ANP, 28 Mar. 2008.

41 Parliamentary Papers, the Netherlands, Second Chamber I979/80, I 5 5 6, no. 9, letter to the chairman of the Antilles Parliament. 
been consulted beforehand and thus could rightfully claim compensation. A joint commission was appointed to set the amount. The Antillean government claimed 40 million Antillean guilders, but failed to back this up, presumably because it found proving a loss difficult at a time of rising tax revenues and foreign exchange income (Van Beurden 20I8, p. I36). ${ }^{42}$ In the end no compensation was paid.

The angry reactions from Curaçao were probably inspired by a fear of more to come. At the same time the Dutch government was busy reconsidering the BRK terms and conditions so as to limit the tax loss on dividends flowing from the Netherlands to Curaçao. As mentioned above, the government had followed up on the BRK by making the Netherlands an attractive tax haven through a wide range of advantageous bilateral tax treaties. Royalties, dividends or other payments could be sent, taxed at low rates or not at all, from partner countries to Dutch shell companies whose income was also subject to a low tax rate provided the money was passed on. By I980 this had become a widely known tax-avoidance opportunity in international business. In I982, for instance, Ingvar Kamprad, his flatpack furniture empire fast expanding around the world, set up a Dutch stichting (foundation) for his patents, ownership rights and royalties (Van Dijk et al. 2006, p. I 8). Film producers and pop stars also discovered how to reduce tax on international rights payments or tour revenues via Dutch shell companies (De Kam I977a). The growth of the Netherlands as an international money transit hub had the effect of boosting Curaçao's position as OFC since as often as not the money went there. However, the widening network of tax treaties and the increasing international tax competition also increased the alternatives available to multinationals and thus formed a threat to the island's competitive position, which as yet remained hidden.

As the flow of money via the Netherlands increased, treaty partners began complaining about tax losses necessitating treaty revision. Forced to act, The Hague decided to tax dividends destined for Curaçao with a rate sufficiently high to stop treaty partners from complaining, yet low enough so as not to harm the flow's volume for, as an internal memo put it, 'The Netherlands has become a financial hub at least in part because of the Antillean Window. ${ }^{43}$ In February I98 I the Ministry of Finance announced that it wanted the BRK revised. ${ }^{44}$ At the same time the tax department started tackling some blatant examples of tax avoidance. In I98 I only three Curaçao shell companies received 60 per cent of dividends sent over from the Netherlands, or I.I billion guilders, for instance (Van Beurden 2018, pp. I 38 table I5, I39). ${ }^{45}$ Subtly increasing the pressure on negotiations, the Ministry of Finance asked for more information about them from its counterpart overseas. In response, the Antillean government reverted to its usual tactic of

42 Parliamentary Papers, the Netherlands, Second Chamber I984/85, Transactions 5 June I98 5, p. 5476.

43 NL-HaNA, Fin/IFZ, 2.08.5229, inv. no. IOO, memo accompanying a letter dated Io Nov. I982 to the Dutch secretary of state at the Ministry of Finance.

44 NL-HaNA, Fin/IFZ, 2.08.5229, inv. no. IOO, letter I2 Feb. I98 I to the Antillean minister of finance.

45 NL-HaNA, Fin/IFZ, 2.08.5229, inv. no. Ioo, letter 2 Apr. 1982 to the Antillean minister of finance. 
soft-pedalling and highlighting the threat of social unrest from any offshore revenue loss, while smartly reminding The Hague that any changes to the BRK would also harm Dutch revenues from the Antillean Window. ${ }^{46}$ It was to no avail: the Netherlands pushed through a revision taxing outflowing dividends at 7.5 per cent with the aim of arriving at a total of I0.5 per cent, assuming the Antillean rate to be 3 per cent. Should that rise to 5 per cent, the Dutch rate would be lowered to 5.5 per cent. Interest payments and royalties remained tax exempt, but a new information exchange clause was meant to subject potential abuse of those exemptions to inspection. ${ }^{47}$ Because the Antillean government deducted some costs from dividends received the tax worked out in practice at 8.3 per cent and that looked a lot, but it was a trifle compared to the normal rate of 25 per cent (Vanenburg and Kattouw 2002, p. I5; Van Beurden 2018, pp. I42-4). ${ }^{48}$ Thus the Antillean Window remained as attractive as before, and for both countries.

The extent to which the Netherlands watched its own interests is highlighted by its sharp reaction when Antillean financial ingenuity harmed them. In I989 Curaçao launched a scheme, to become known as the Pensionado Scheme, to attract wealthy pensioners and rentiers from abroad by granting them a conditional 5 per cent income tax rate. ${ }^{49}$ The target group included people close to retirement, who could profit from the low tax rate by resigning from their job, moving to Curaçao and cashing in their pension rights. ${ }^{50}$ The scheme was an immediate success. Numerous prominent and wealthy people from the worlds of business, entertainment and politics moved from the Netherlands to the Antilles, for real or just on paper. ${ }^{51}$ Others moved their personal pension pots to Curaçao shell companies. One case in the public spotlight was that of the minister for economic affairs, Hans Wijers, member of a cabinet which considered the Pensionado Scheme an abuse of the BRK. ${ }^{52}$

The Antilles fully realised the abuse and had launched the scheme as a provocation, considering it likely that the Netherlands would stop it. It did indeed, with legislation that made cashing pensions by pension shells from abroad subject to a corporate tax of 60 per cent. ${ }^{53}$ Entirely closing the loophole required a new revision of the BRK, however, and those talks proved so difficult that the Dutch government openly threatened cancellation of the BRK to force the Antilles into agreement. ${ }^{54}$ It was partly bluffing, but the negotiators in The Hague expected the Antilles to give way

\footnotetext{
46 NL-HaNA, Fin/IFZ, 2.08.5229, inv. no. Ioo, letter 7 July I982 to the Dutch minister of finance.

47 Nederlandse Staatscourant, I2 Apr. I984.

48 Parliamentary Papers, the Netherlands, Second Chamber 200I/O2, 27 910, no. 5, p. I.

49 Parliament Netherlands Antilles I989-I990-I205, cover statement.

50 Het Financieele Dagblad, 29 Nov. I99I.

51 Amigoe, I2 Feb. I992.

52 Het Financieele Dagblad, 3 I Aug. I994.

53 Parliamentary Papers, the Netherlands, Second Chamber I994/95, 23046, no. I8.

54 Amigoe, 25 Apr. I995.
} 
because of the expected harm if the BRK were terminated; that is indeed what happened. The Antillean government accepted the revised BRK plus a sharply reduced scope for the Pensionado Scheme (Metry 2006, p. 686). Thus The Hague closely guarded its own interests. The dividend flows were spared as far as possible and the corporate tax break kept in place so as to avoid harming the country's fiscal competitiveness and keep the financial sector, legal and accounting services, and corporate interests happy. By contrast, the Pensionado Scheme was sunk because Curaçao's gain from that tax wheeze was the Netherlands' loss.

As the Pensionado Scheme controversy ran its course other and wider-ranging issues surfaced that affected both the relations between the two countries and Curaçao's OFC. In 1992 the EU dropped the withholding tax on dividend payments from subsidiaries to parent companies within the union, prompting corporations to move subsidiaries from OFCs like Curaçao to member countries such as Luxemburg. As a result dividends paid from the Netherlands to Curaçao dropped sharply, from around one billion Dutch guilders during the years 1989-93 to some IOO-200 million during the second half of the I990s (Van Beurden 20I8, p. 2 I2). The Antillean government immediately demanded equal treatment with member countries from the Netherlands, that is to say no withholding tax on dividends paid to Curaçao. ${ }^{55}$ The Dutch government not only refused this, in I997 it passed legislation stimulating multinationals to repatriate finance subsidiaries back to the Netherlands. Six leading multinationals, including Philips, Heineken and the supermarket chain Albert Heijn, seriously considered doing so or in effect did repatriate (Van Beurden 2018, pp. 219-20).

The I990s also saw a growing international concern with tax avoidance and tax evasion, money laundering and financial stability. Though the OECD and the EU limited themselves to non-binding reports about tax avoidance and evasion and fiscal competition, their lists of jurisdictions specialising in such practices helped to change public opinion about using OFCs from generally accepted to doubtful or even dubious. In 1989 the $\mathrm{G} 7$ group of countries launched the Financial Action Task Force on Money Laundering (FATF), considerably widening its remit in I996 and 200I. The task force issued detailed recommendations to countries about combating money laundering, monitored compliance and punished non-compliers by blacklisting them. The Financial Stability Forum (FSF), set up by the G7 after the I997 Asian financial crisis, did the same for banking supervision. Attempts to combat the financing of terrorist organisations following the 9/I I attack on the New York World Trade Center increased the pressure on OFCs to adopt international standards of supervision, transparency and information exchange.

All OFCs dragged their feet in toeing the new lines, but several of them had, unlike Curaçao, a comparative advantage to exploit that ensured their continuing attractiveness. Ireland and Malta could offer access to the EU. Switzerland relied successfully on 
its huge network and OECD membership. Since receiving the first captive insurance company in I962, Bermuda combined a leading position as international insurance and re-insurance hub with a zero-tax regime ('Sir Henry Tucker'; Palan et al. 20 Io, pp. I26-7). The Cayman Islands combined its zero-tax regime with strict secrecy legislation to specialise in attracting hedge funds and captive insurance companies (Roberts I995, p. 242; Palan et al. 2010, pp. I37, I67). The Bahamas sought to bolster its competitive advantage by opening facilities to set up offshore companies cheap and fast, within 24 hours (Vanderbruggen I996, p. I92; Zephirin and Seerattan I997, p. 322). The British Virgin Islands used zero-tax and light corporate legislation to turn itself into the world leader in registered offshore companies, which numbered I.I million in 2013 (Maurer I995, p. I 59; Doggart 2002, p. 242). Barbados succeeded in remaining a diversified OFC with a wide tax treaty network, flexible corporate legislation and special facilities for captives (Doggart 2002, p. I9).

Compared to these rivals the Antilles had little to offer that was unique or worthwhile for counterparties. Despite the Dutch government's earnest efforts, big countries, realising they had only tax revenues to lose, refused to let the Antilles join bilateral tax treaties with the Netherlands. During the I99os the US and eight other countries including Brazil and China took that stance (Van Beurden 20I8, pp. 230-2). Attempts to prevent Curaçao from being blacklisted by the OECD succeeded in the sense that, with firm Dutch support, the Antilles managed to conclude a series of Tax Information Exchange Agreements (TIEAs) promoted by the OECD. However, the agreements failed to bring any advantage because all major OFCs got the same or similar ones, while the tortuous procedure of obtaining the required fiscal information rendered the TIEAs essentially meaningless.

The loss of its competitive position combined with the lack of local consensus about how best to rebound and the EU's guidelines about withholding tax to send the Curaçao offshore into contraction. The number of shell companies, offshore banks and trust companies dropped and even big local trust companies like Citco and Amicorp shifted their main operations elsewhere, causing the Dutch Citco branch to outgrow its Curaçao parent (Van Beurden 20I8, pp. 3I4-I6). Consequently, public revenue from profit taxes and foreign exchange fell sharply, causing widening budget deficits, the result of previous heavy spending on a bloated civil service and on public services expansion (Haan I998, pp. 218-i9; Van Beurden 20I8, p. 3 I 8 graph I2, p. 344 annex I). In 2008, the Curaçao politician G. Damoen accused the Netherlands of having killed its healthy OFC. ${ }^{56}$

This was unfair in the sense that several other factors caused Curaçao to decline. Yet it is hard not to sympathise with Damoen's chagrin, because while the Curaçao OFC declined, the Netherlands continued to strengthen its position as international money transfer hub. In I994, parliament passed legislation defining the statute and reporting duties of Special Financial Institutions (Bijzondere Financiële Instellingen or BFIs), in 
effect a formalisation of the various shell company forms that had existed until then. ${ }^{57}$ Estimates about the number of these BFIs range from I2,000 to I4,400. The Dutch government favours these shells for the same reason as Delaware or New Jersey. In 2007 , they generated an estimated one billion euros in tax revenues plus 500 million euros in fees for specialised service providers. ${ }^{58}$ Multinationals including car manufacturers Fiat Chrysler and Nissan-Renault or the Russian internet giant Yandex have their formal base in the Netherlands. The mooted merger between Fiat Chrysler and Peugeot Citroën will probably also choose to have its legal seat in the Netherlands for the same reason: fiscal optimisation of their international revenues. The Tax Justice Network (TJN) estimated the total flow-through in 2017 at 4 trillion euros, ten times Dutch GDP. ${ }^{59}$ Though the Dutch central Bank, DNB, claims to supervise the BFIs, it remains difficult, not to say impossible, to determine who gains from these tax benefits or, conversely, who loses from them. The suspicion that these institutions facilitate tax evasion is stronger than ever. It is no surprise that the Netherlands moved up in the TJN's periodically updated Financial Secrecy Index, from forty-first place in 2015 to fourteenth in 20I8. At the same time, Curaçao dropped from no. 70 to 84 , a fact with which Willemstad unfailingly counters Dutch criticism of its OFC.

\section{VIII}

Tax havens or OFCs are set up to generate public revenue by attracting corporations and HNWIs from elsewhere. They arise and exist in response to the demand for their services from financial centres elsewhere and are thus manifestations of a new form of dependency. Our analysis of the symbiosis between the Netherlands and Curaçao demonstrates this in detail. Curaçao was definitely highly inventive and active in developing a wide range of services and facilities, yet its evolution as an OFC was prompted by Dutch initiatives, boosted by Dutch multinationals and service providers, and supported by Dutch foreign policy throughout. For some 30 years the two countries worked in tandem. The Curaçao OFC benefitted from being associated with the Netherlands, its trustworthy legal system and its range of bilateral tax treaties. Conversely, Curaçao helped to build the Netherlands into the big international money transfer hub which it is today.

The loss of the big American advantages during the I980s exposed the weaknesses of Curaçao's competitive position, that is to say, its close focus on the US and on the Netherlands and its lack of specialisation. A divided service sector failed to agree on the best way forward and clung to perceived comparative advantages, such as its ability to launch tailormade products like the Pensionado Scheme and its hallowed

57 This happened with the so-called Wet financiële betrekkingen buitenland 1994, Staatsblad I994, 258.

58 De Nederlandsche Bank, Quarterly Report 2007, p. 66: www.dnb.nl/binaries/Bijzondere\%2ofinancele\%2oinstellingen_tcm46-I 47240.pdf

59 www.financialsecrecyindex.com/PDF/Netherlands.pdf (accessed 7 Dec. 2019). 
confidentiality. The former foundered on Dutch objections, the latter proved to offer little or no edge in the increasingly tough competition between OFCs. These developments combined to send Curaçao's OFC into a decline from which it has yet to recover. At the same time the Netherlands continued to enjoy a key financial hub position originally built on the country's symbiosis with Curaçao. This aspect, Western countries' profit from OFCs, deserves more attention than it usually gets.

Submitted: 8 January 2020

Revised version submitted: 25 June 2020

Accepted: 24 August 2020

First published online: I4 January $202 \mathrm{I}$

\section{Sources}

Amigoe di Curaçao

$A N P$

Financial Times

Herald Tribune

Het Financieele Dagblad

National Archives, The Hague

- 2.05.263, Diplomatic Embassies: USA

- 2.08.75, Ministry of Finance: Financial Attaché New York and Washington, I940-74

- 2.08.5229, Ministry of Finance/IFZ

- 2.I0.4 I, Kabinet Vice-PM/ KabSNA

- 2.20.0 I, NHM

Nederlandse Staatscourant

New York Times

NRC-Handelsblad

Parliamentary Papers, the Netherlands

Parliamentary Papers, the Netherlands Antilles

Utrechts Nieuwblad

\section{References}

ASSEMBLÉE NATIONALE (2000). Rapport d'information sur les obstacles au controle et à la répression de la délinquance financière et du blanchiment des capitaux en Europe, vol. I: La Principauté du Liechtenstein. Paris: Assemblée nationale.

BEERS, H. C. (I980). An Introduction to the Financial System of the Netherlands Antilles. Willemstad: Bank van de Nederlandse Antillen.

BEURDEN, M. J. C. VAN (2018). De Curaçaose offshore: Ontstaan, groei en neergang van een belastingparadijs, I95I-20I3. PhD dissertation, University of Amsterdam.

BOISE, C. M. and MORISS, A. P. (2009). Change, dependency, and regime plasticity in offshore financial intermediation: the saga of the Netherlands Antilles. Texas International Law Journal, 45(2), pp. $377-456$.

DIJK, M. VAN, WEYZIG, F. and MURPHY, R. (2006). The Netherlands: A Tax Haven? Amsterdam: SOMO.

DOES DE WILLEBOIS, E., HALTER, E. M., HARRISON, R. A., PARK, J. W. and SHARMAN, J. C. (20 I I). The Puppet Masters: How the Corrupt Use Legal Structures to Hide Stolen Assets and What to Do About It. Washington, DC: World Bank.

DOGGART, C. (2002). Tax Havens and Their Uses. London: The Economist Intelligence Unit.

DYRENG, S. D., LINDSEY, B. P. and THORNOCK, J. R. (2OI3). Exploring the role Delaware plays as a domestic tax haven. Journal of Financial Economics, 108, pp. 75 I-72.

FEHRENBACH, T. R. (I966). The Gnomes of Zurich. London: Leslie Frewin. 
GALlAGHER, R. (I990). Survey of Offshore Finance Sectors in the Caribbean Dependent Territories. London: HMSO.

GODEFROY, T. and LASCOUMES, P. (2004). Le capitalisme clandestin. Paris: Éditions La Découverte.

GORDON, R. A. (I98I). Tax Havens and Their Use by United States Taxpayers. Washington, DC: U.S. Internal Revenue Service (IRS).

GRAAF, T. DE (20I2). Voor handel en maatschappij, geschiedenis van de Nederlandsche Handel-Maatschappij, 1824-1964. Amsterdam: Boom.

GUEX, S. (I999). Les orgines du secret bancaire suisse et son rôle dans la politique de la confédération au sortir de la Seconde Guerre mondiale. Genèses, 34, pp. 4-27.

HAAN, T. J. (1998). Antilliaanse instituties, de economische ontwikkeling van de Nederlandse Antillen en Aruba, 1960-1995. Capelle a/d IJssel: Labyrint Publication.

HAGEN, J. (I989). Offshore Banking Centers: The Case of Curaçao. Coral Gables: unknown. [Revised and updated, I990, Curaçao: unknown.]

HAMPTON, M. P. (I996). The Offshore Interface: Tax Havens in the Global Economy. Basingstoke: Palgrave Macmillan

HARTOG, J. (I993). De geschiedenis van twee landen, de Nederlandse Antillen en Aruba. Zaltbommel: Europese Bibliotheek.

HOWARTH, S. and JONKER, J. P. B. (2007). A History of Royal Dutch Shell, vol. II: Powering the Hydrocarbon Revolution, 1939-1973. Oxford: Oxford University Press.

HUDSON, A. C. (I998). Reshaping the regulatory landscape: border skirmishes around the Bahamas and Cayman offshore financial centres. Review of International Political Economy, 5, pp. 534-64.

IMF (2000). Offshore financial centers. IMF Background Paper. Washington, DC: IMF.

JOHNS, R. A. (1983). Tax Havens and Offshore Finance: A Study of Transnational Economic Development. New York: St Martin's Press.

JOINT COMMISSION OF EXPERTS (I979). Aanzet tot een integraal beleidskader voor de Nederlandse Antillen in de jaren tachtig. The Hague and Willemstad: SDU.

JONG, T. DE (2018). Groot geld op Curaçao: afscheid van een belastingparadijs. Volendam: LM Publishers.

JONKER, J. P. B. and VAN ZANDEN, J. L. (2007). A History of Royal Dutch Shell, vol. I: From Challenger to Joint Industry Leader, 1890-1939. Oxford: Oxford University Press.

KAGIE, R. (I982). De laatste kolonie. Bussum: Het Wereldvenster.

KAM, C. A. DE (I977a). Betalen is voor de dommen: over de miljardenmazen in ons belastingstelsel. Amsterdam: Bert Bakker.

KAM, C. A. DE (I977b). Het belastingparadijs Nederland. NRC-Handelsblad Z, 7, I4 May I977, pp. 4, 7.

KAM, C. A. DE (I983). Antillenroute bedreigd. Intermediair, I9, pp. I-3.

KONINGSVELD, T. J. VAN (2015). De Offshore wereld ontmaskerd: een studie naar aard en omvang van het misbruik maken van offshore vennootschappen door Nederlandse (rechts)personen. Almere: Kerckebosch.

LANG, M. (200I). Die Entwicklung des Unternehmensrechts der Niederländischen Antillen. Münster: Waxmann Verlag.

MATHIESON, J. A. and LAUDICINA, P. A. (I982). The Netherlands Antilles: The Impact of Offshore Financial Activities. Final Report. Washington, DC: SRI International.

MAURER, B. (I995). Orderly families for the new economic order: belonging and citizenship in the British Virgin Islands. Identities: Global Studies in Culture and Power, 2, pp. I49-7I.

METRY, F. (2006). De geschiedenis van de belastingen in de kolonie Curaçao en de Nederlandse Antillen. Curaçao: Stichting Publicaties KPMG Tax and Legal Services.

PALAN, R. (2002). Tax havens and the commercialization of state sovereignty. International Organization, 56, pp. I $5 \mathrm{I}-76$.

PALAN, R. (2006). The Offshore World: Sovereign Markets, Virtual Places, and Nomad Millionaires. Ithaca, NY: Cornell University Press.

PALAN, R. (2009). The history of tax havens. www.historyandpolicy.org (accessed 7 February 20 I7).

PALAN, R. (20I0). International finance centers, the British Empire, city-states and commercially oriented politics. Theoretical Inquiries in Law, II, pp. I49-76.

PALAN, R., MURPHY, R. and CHAVAGNEUX, C. (20Iо). Tax Havens: How Globalization Really Works. Ithaca, NY: Cornell University Press.

PAPKE, L. E. (2000). One-way treaty with the world: the U.S. withholding tax and the Netherlands Antilles. International Tax and Public Finance, 7, pp. 295-3 I 3. 
QUILLEN, W. T. and HANRAHAN, M. (I993). A short history of the Delaware Court of Chancery I792-I992. Delaware Journal of Corporate Law, I8, pp. 8 I9-66.

ROBERTS, R. (I994). Introduction. In R. Roberts (ed.), Offshore Financial Centres. Aldershot: Edward Elgar Publishing.

ROBERTS, R. (I996). The economics of cities of Finance. In H. Diederiks and D. Reeder (eds.), Cities of Finance. Amsterdam and New York: North Holland.

ROBERTS, S. M. (I995). Small places, big money: the Cayman Islands and the international financial system. Economic Geography, 7I, pp. 237-56.

'SIR HENRY TUCKER'. Bermudabiographies. www.bermudabiographies.bm (accessed 24 October 20I5).

SMEETS, A. A. G. (I985). Ontwikkeling van de offshore-activiteiten op de Nederlandse Antillen. In O. B. Linker (ed.), Opstellen ter gelegenheid van het 100-jarig bestaan van de Kamer van Koophandel en Nijverheid te Curaçao. Curaçao: Kamer van Koophandel en Nijverheid.

SOEST, J. VAN (I976). Olie als water: de Curaçaose economie in de eerste helft van de twintigste eeuw. Curaçao: Hogeschool van de Nederlandse Antillen.

SOEST, J. VAN (1978). Trustee of the Netherlands Antilles. Zutphen: De Walburg Pers.

SOEST, J. VAN (I980). On the account of Curaçao. Social and Economic Studies, 29, pp. 220-46.

TROMP, E. (I (999). Een terugblik op de Antilliaanse economie: de 'Lio-factor'. In H. E. Coomans et al. (eds.), Veranderend Curaçao: collectie essays opgedragen aan Lionel Capriles ter gelegenheid van zijn 45-jarig jubileum bij de Maduro \& Curiel's Bank NV. Bloemendaal: Stichting Libri Antilliani.

VANDERBRUGGEN, P. (I996). Belastingparadijzen. Amsterdam/Antwerp: Meulenhoff/Kritak.

VANENBURG, S. R. and KATTOUW, A. (2002). Het Nieuw Fiscaal Raamwerk op de Nederlandse Antillen. De Antillen als nieuwe vestigingsplaats voor de internationale financiële dienstensector. Amsterdam: PricewaterhouseCoopers.

VLCEK, W. (2009). A semi-periphery to global capital, global governance and lines of flight for Caribbean offshore financial centres. In O. Worth and P. Moore (eds.), Globalisation and the 'New' Semi-Peripheries. Basingstoke: Palgrave Macmillan.

VLCEK, W. (20I2). Contingent liability or moral hazard after the global financial crisis: Cayman, Westminster and global finance. In P. Clegg and D. Killingray (eds.), The Non-Independent Territories of the Caribbean and Pacific: Continuity and Change London: Institute of Commonwealth Studies.

VLCEK, W. (20I7). Offshore Finance and Global Governance: Disciplining the Tax Nomad. Basingstoke: Palgrave Macmillan.

WHYTE, M. N. (1985). De offshore sector op Curaçao: niet alleen een begrip in zee. MA thesis, Radboud Universiteit Nijmegen.

ZEPHIRIN, M. G. and SEERATTAN, D. (1997). Financial Innovations in the Caribbean. St Augustine: Caribbean Centre for Monetary Studies.

ZOROMÉ, A. (2007). Concept of offshore financial centers: in search of an operational definition. IMF Working Paper 07/87. 
Appendix: The number of offshore companies and offshore banks in six OFCs

Table Aı. The number of offshore-companies on Curaçao, the Bahamas, Barbados, Bermuda, British Virgin Islands, the Cayman Islands and Delaware, 1967-2013

\begin{tabular}{|c|c|c|c|c|c|c|c|}
\hline I967 & Curaçao & Bahamas & Barbados & Bermuda & BVI & Cayman & Delaware \\
\hline I967 & $\mathrm{I}, 250$ & & & & & & \\
\hline I968 & - & & & & & & \\
\hline I969 & $\mathrm{I}, 350$ & & & & & & \\
\hline I970 & - & $\mathrm{I} 2,000$ & & & & 2,000 & \\
\hline I97 I & $\mathrm{I}, 500$ & & & & & 2,500 & \\
\hline I972 & $\mathrm{I}, 950$ & & & & & 3,500 & \\
\hline I974 & & & & & & 6,000 & \\
\hline I975 & 2,900 & $\mathrm{I} 4,000$ & & & & & \\
\hline I976 & 4,000 & & & 3,330 & & 7,520 & \\
\hline I977 & 4,500 & & & & & & \\
\hline I978 & 6,900 & & & & & & \\
\hline I980 & - & & & & & $\mathrm{I} 2, \mathrm{OOOO}$ & \\
\hline I982 & 25,000 & & & & & & \\
\hline I983 & 25,000 & & & & & I7,000 & \\
\hline I984 & 27,850 & & & 5,030 & & & \\
\hline I985 & 25,500 & & & & & & \\
\hline I986 & 22,000 & & & & & & \\
\hline I987 & 20,500 & & & & & I 8,265 & \\
\hline I988 & I9,300 & & & & $\mathrm{I} 3,000$ & & \\
\hline I989 & I 8,200 & & & & - & & \\
\hline I990 & I 8,600 & & & & 35,900 & & \\
\hline I99I & I9, IOO & & & 5,700 & - & 24,000 & \\
\hline I992 & I9,500 & & & - & - & - & \\
\hline
\end{tabular}


Table Ar. Continued

\begin{tabular}{|c|c|c|c|c|c|c|c|}
\hline I967 & Curaçao & Bahamas & Barbados & Bermuda & BVI & Cayman & Delaware \\
\hline I993 & 20,700 & & & 7,300 & IOO,OOO & 25,000 & \\
\hline I994 & $2 \mathrm{I}, \mathrm{I} 5 \mathrm{O}$ & 28,500 & 2,650 & 8,500 & - & $3 \mathrm{I}, 600$ & \\
\hline I995 & $2 \mathrm{I}, 200$ & 39,000 & 3,340 & & I 62,800 & & \\
\hline I996 & - & $5 \mathrm{I}, 200$ & 3,850 & & & & \\
\hline I997 & 21,000 & 69,900 & 4,920 & & & & \\
\hline I998 & - & 84,500 & 5,680 & & & & \\
\hline I999 & 20,700 & IOO, IOO & 6,260 & & & & \\
\hline 2000 & 20,100 & & 6,830 & I 5,200 & & 49,500 & \\
\hline $200 \mathrm{I}$ & 20,100 & & 7,040 & & $3 \mathrm{I} 4,000$ & & \\
\hline 2002 & I9,800 & & & & & & \\
\hline 2003 & I 8, I 50 & & & & & & \\
\hline 2004 & 17,225 & & & & & & \\
\hline 2005 & I 6, I 40 & & & & 626,800 & & \\
\hline 2006 & - & I I 5,000 & & & 802,800 & 62,600 & \\
\hline 2007 & - & & 30,000 & I 3,800 & & 78,500 & \\
\hline 2008 & $\mathrm{I} 4,000$ & & & & & & 882,000 \\
\hline 2009 & & & & & & & 879,000 \\
\hline 2010 & - & & & & 948,000 & $9 \mathrm{I}, 200$ & 909,000 \\
\hline $20 \mathrm{II}$ & & & & & & & 945,000 \\
\hline 2012 & IO,OOO & & & & & & $\mathrm{I}, \mathrm{OOO}, \mathrm{OOO}$ \\
\hline 2013 & 9,840 & I 66,200 & & I 5,200 & $\mathrm{I}, \mathrm{I} 3 \mathrm{O}, \mathrm{OOO}$ & 92,000 & $\mathrm{I}, 052,000$ \\
\hline
\end{tabular}

Sources: Van Beurden 2018, pp. I25, I84, 243, 3 I9; https://corp.delaware.gov/archived-annual-reports/ (accessed 30 May 2020). The Delaware numbers are for all business entities in the state, the majority of which are almost certainly offshore entities. 
Table A2. The number of offshore banks on Curaçao, the Bahamas and the Cayman Islands, 1967-75

\begin{tabular}{|c|c|c|c|c|}
\hline Year & Curaçao & Bahamas & Barbados & Cayman \\
\hline I967 & & 200 & & \\
\hline I968 & & $2 \mathrm{IO}$ & & \\
\hline I969 & 2 & 260 & & \\
\hline I970 & & 300 & & 35 \\
\hline I97 I & 3 & 3 I 5 & & 50 \\
\hline I972 & 5 & 330 & & 80 \\
\hline I973 & 8 & 320 & & I 30 \\
\hline I974 & $\mathrm{I} 2$ & 300 & & I 80 \\
\hline I975 & I 4 & 280 & & I90 \\
\hline I976 & I 4 & 255 & & 205 \\
\hline I977 & 19 & 260 & & 215 \\
\hline I978 & $2 \mathrm{I}$ & 275 & & 240 \\
\hline I979 & 24 & 290 & & 270 \\
\hline I980 & $3 \mathrm{I}$ & 300 & & $3 \mathrm{IO}$ \\
\hline I98 I & 38 & 350 & 2 & 380 \\
\hline I982 & 38 & 345 & 2 & $4 \mathrm{IO}$ \\
\hline I983 & 39 & 360 & 5 & 420 \\
\hline I984 & 42 & 365 & 5 & 430 \\
\hline I985 & 46 & 370 & 5 & 480 \\
\hline I986 & 50 & 370 & 5 & 490 \\
\hline I987 & $5 \mathrm{I}$ & 375 & 5 & 500 \\
\hline I988 & $5 \mathrm{I}$ & 390 & 6 & 520 \\
\hline I989 & 53 & 390 & 7 & 530 \\
\hline I990 & 54 & 400 & I 3 & 540 \\
\hline I99I & & 400 & I3 & 540 \\
\hline I992 & & - & I6 & 534 \\
\hline I993 & & - & $2 \mathrm{I}$ & \\
\hline I994 & & $4 \mathrm{I} 3$ & 28 & \\
\hline I995 & 42 & $4 \mathrm{IO}$ & 32 & \\
\hline I996 & & 425 & 40 & \\
\hline I997 & & $4 \mathrm{I} 8$ & 44 & \\
\hline I998 & & $4 \mathrm{I} 8$ & 43 & \\
\hline I999 & 45 & $4 \mathrm{I} 5$ & 47 & 450 \\
\hline 2000 & & $4 \mathrm{IO}$ & 52 & \\
\hline $200 \mathrm{I}$ & & & 56 & \\
\hline 2003 & & $30 \mathrm{I}$ & & \\
\hline 2006 & & I 39 & & 450 \\
\hline 2013 & 32 & & & \\
\hline
\end{tabular}

Source: Van Beurden 2018, pp. I25, I84, 243, 320. 